\title{
Antimicrobial Photodynamic Activity of Phthalocyanine Derivatives
}

\author{
Samuel N. Nyamu $\left(\mathbb{D},{ }^{1}\right.$ Lucy Ombaka, ${ }^{2}$ Eric Masika, ${ }^{1}$ and Margaret Ng'ang' a ${ }^{1}$ \\ ${ }^{1}$ Department of Chemistry, Kenyatta University, P.O. Box 43844-00100, Nairobi, Kenya \\ ${ }^{2}$ Department of Chemical Science and Technology, Technical University of Kenya, P.O. Box 52428-00200, Nairobi, Kenya \\ Correspondence should be addressed to Samuel N. Nyamu; nyamusamnju@gmail.com
}

Received 27 September 2017; Revised 11 December 2017; Accepted 15 January 2018; Published 19 March 2018

Academic Editor: Viktor O. Iaroshenko

Copyright (c) 2018 Samuel N. Nyamu et al. This is an open access article distributed under the Creative Commons Attribution License, which permits unrestricted use, distribution, and reproduction in any medium, provided the original work is properly cited.

\begin{abstract}
Microbial pathogens have increasingly shown multidrug resistance posing a serious threat to the public health. Advances in technology are opening novel avenues for discovery of compounds that will mitigate the ever-increasing drug-resistant microbes. Use of photodynamic photosensitizer is one of the promising alternative approaches since they offer low risk of bacteria resistance as they use generated reactive oxygen species to kill the microbes. Phthalocyanine $(\mathrm{Pc})$ is one such photosensitizer which has already shown promising antimicrobial photodynamic therapeutic properties. Previous studies have shown effectiveness of the Pc against Gram-positive bacteria. However, its effectiveness toward Gram-negative bacteria is limited by the impermeability of the bacteria's outer membrane which is made up of lipopolysaccharides layer. The effectiveness of this photosensitizer is determined by its photophysical and photochemical properties such as singlet/triplet lifetimes, singlet oxygen quantum yields, and fluorescence quantum yield. Therefore, this review focuses on the recent significance advances on designing Pc that have this improved property by either conjugating with nanoparticles, quantum dots, functional groups in peripheral position, considering effect of cationic charge, and its position on the macrocycle.
\end{abstract}

\section{Introduction}

Drugs that are effective against microbes are used in both curative and preventive measures in protecting patients against diseases that are fatal to the extent of some resulting in death. Despite the extensive research in area of microbial pathogenesis and the emergence of new antibiotic drugs in the market, morbidity and mortality linked with the pathogens infections keep on increasing $[1,2]$. There is alarming growth in antibiotic resistance by pathogenic microbes with an estimate of $45 \%$ of all deaths being caused by pathogenic microbes [3]. Antimicrobial resistance is thus one of the most serious health threats. This calls for new effort to discover new ways of eradicating these microbial pathogens [4].

The use of photosensitizers and light is complementary as well as alternate method to the conventional way of fighting against pathogenic microbes. When light of a specific wavelength is illuminated to such photosensitizer molecule, particles with high reactivity are generated that can destroy pathogenic microbial cells [5]. Previous studies have reported high quantum yield of oxygen production, high photo toxicity when light of specific wavelength is illuminated on them, and high stability in physiological conditions $[6,7]$. Photosensitizers that are currently being studied in fighting these microbes include porphyrins, phenothiazines, and phthalocyanine [7].

\section{Antibiotic Resistance in Some Parts of Africa}

Microbe's causes a big proportion of infection and death in Africa. However, the rise of antibiotic resistance has dented the hope to reduce the infection and death caused by these pathogens [8]. The increasing trend of antibiotic resistance and the slow pace of developing new antibiotics pose a danger to African countries. Resistance to most antibiotics has been shown by microbes like Vibrio cholera which has been 
TABLE 1: Bacterial infections and their respective antibiotic resistance in selected African countries.

\begin{tabular}{|c|c|c|c|}
\hline Country & $\begin{array}{c}\text { Causative } \\
\text { organism/disease }\end{array}$ & Antibiotic resistance & Ref \\
\hline Guinea Bissau & Vibrio cholerae & $\begin{array}{c}\text { Sulfamethoxazole, tetracycline, ampicillin, } \\
\text { aminoglycosides, erythromycin, nalidixic acid, and } \\
\text { trimethoprim }\end{array}$ & {$[8]$} \\
\hline Kenya & Staphylococcus aureus & Methicillin & {$[3,9-11]$} \\
\hline Kenya & Typhoid & Fluoroquinolones & [9] \\
\hline Kenya, Somali & Vibrio cholera & $\begin{array}{l}\text { Tetracycline, ampicillin, chloramphenicol, } \\
\text { cotrimoxazole }\end{array}$ & {$[9,10,12]$} \\
\hline Kenya & E. coli & $\begin{array}{l}\text { Co-trimoxazole, streptomycin, } \\
\text { tetracycline, ampicillin, quinolones, and cephalosporins }\end{array}$ & {$[1,9,10,13]$} \\
\hline $\begin{array}{l}\text { Mozambique, } \\
\text { South Africa }\end{array}$ & Neisseria meningitides & $\begin{array}{l}\text { Ceftriaxone and } \\
\text { chloramphenicol }\end{array}$ & {$[10]$} \\
\hline Zimbabwe & Gonococci isolates & Trimethoprim + sulfamethoxazole & {$[12]$} \\
\hline Rwanda & Shigella & Chloramphenicol, ampicillin, and trimethoprim & {$[12]$} \\
\hline Kenya & H. influenza & Chloramphenicol, amoxicillin, and sulfamethoxazole & {$[12]$} \\
\hline
\end{tabular}

resistant to sulfamethoxazole, tetracycline, ampicillin, aminoglycosides, erythromycin, nalidixic acid, and trimethoprim in some parts of Africa as shown in Table 1 [8]. Staphylococcus aureus (S. aureus) have shown resistance to methicillin; Escherichia coli exhibits resistance to Co-trimoxazole, streptomycin, tetracycline, ampicillin, quinolones, and cephalosporins $[1,6,9,10]$. Isolates obtained from Kenya indicate that $71 \%$ of $S$. aureus demonstrate multidrug resistance to a number of antibiotics [11].

\section{Photosensitizers}

3.1. Properties of a Good Photosensitizer. An effective photosensitizer to be used for photodynamic inactivation of microbes should have minimal dark toxicity and be able to rapidly clear from normal tissue once introduced into the body reducing phototoxic side effects. It requires an absorption peak between 600 and $800 \mathrm{~nm}$ to give it capacity for forming substantial yield of reactive oxygen species upon irradiation with light. A high quantum yield $\Phi \Delta>0.4$ is required as this increases its efficiency to generate singlet oxygen; it needs to have good amphiphilic property, high binding affinity to microbes, and low binding affinity to mammalian cells $[25,26]$ and be chemically pure.

When a photosensitizer absorbs light it gets excited to one or more energy rich states resulting in an internal chemical reaction [27]. This takes place either in a type I reaction or type II reaction as shown in Figure 1.

Type I reaction involves the transfer of an electron between excited photosensitizer and the substrate to generate free radical $[28,29]$. The substrate donates an electron to the photosensitizer making it form a substrate cation and the photosensitizer becomes a radical anion [25]. In the presence of oxygen, they react to form oxygenated product of either superoxide anion or hydroxyl radical, respectively [29]. These compounds alter the functionality of cells or tissues of organism that are exposed to them, thus finding use in fight against pathogenic microbes. In type II reaction the excited

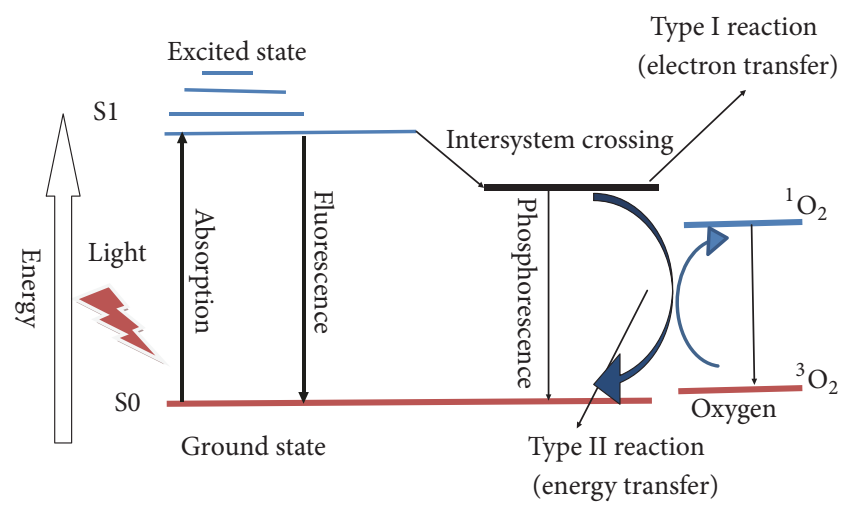

FIGURe 1: Type I and type II reactions.

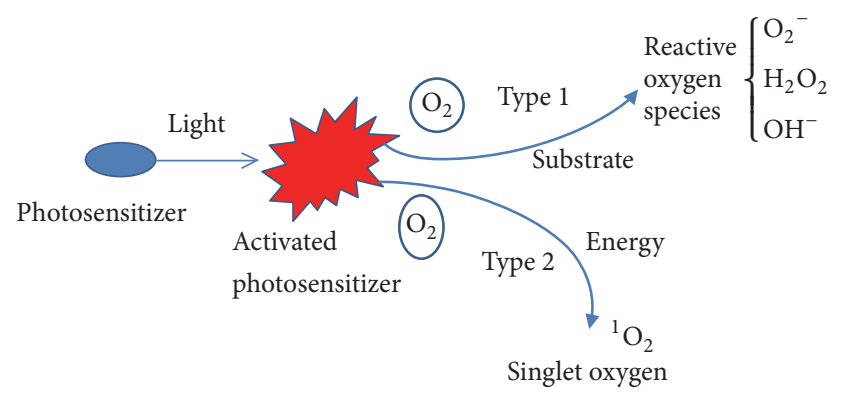

FIGURE 2: Generation of singlet oxygen and reactive oxygen species.

sensitizer transfers its excess energy in the triplet state to a ground state molecular oxygen $\left({ }^{3} \mathrm{O}_{2}\right)$ resulting in a singlet oxygen that is excited $\left({ }^{1} \mathrm{O}_{2}\right)[16,30]$. This singlet oxygen then reacts with the substrate to produce superoxide and hydroxyl oxygenated products [29] (Figure 2). The compound formed and the singlet oxygen are very toxic when they interact with cells or tissues of the targeted microbes since both can cause damage to biological membrane and DNA [25]. 


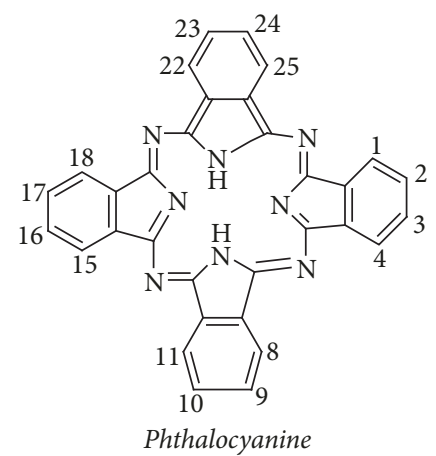

FIGURE 3: Positions where substitution can occur in nonmetalleted Pc.

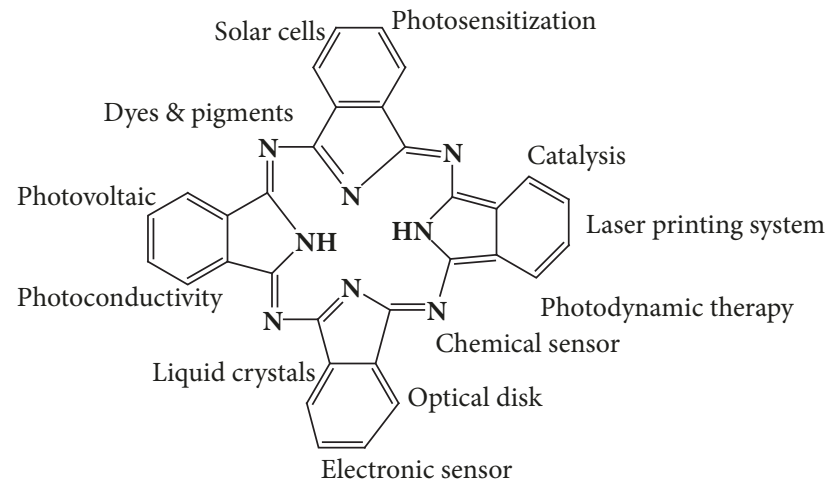

FIgURE 4: Applications of phthalocyanine derivatives.

\section{Phthalocyanine}

Phthalocyanine has exceptional physical and chemical properties that allow many elements to be included within its structure as compared to other photosensitizers. Its chemical flexibility makes it possible to attach different substituents at peripheral position and enables it to have many uses [31].

Pc has 16 positions where substitution may occur and this greatly affects its chemical properties. It may attach at nonperipheral $(\alpha)$ position or peripheral $(ß)$ positions of planar macrocycle structure of Pc. When a functional group attaches at position $2,9,16,23$ or 2,3,9,10,16,17,23,24, it is termed as peripheral position, while a functional group attaching at 1,8,15,22 or 1,4,8,11,15,18,22,25 position is termed as nonperipheral position. It may also occur at central axial position where metals can attach [16] (Figure 3).

\section{Applications of Phthalocyanine}

Macrocyclic chemistry of phthalocyanine has attracted much interest because of its chemical properties and use in different areas (Figure 4).

Pc derivatives are finding use in liquid crystals as new type of organic semiconductor with high viscosity and high bulk mobility [32]. They are used in solar cells, for example, copper phthalocyanine: $\mathrm{C}_{60}$, because of their wider spectral range, higher hole mobility, and longer diffusion exciton length [33]. In catalysis metal phthalocyanine is used in degradation of pollutants. For example, chlorophenols which is an industrial waste can be removed by oxidation catalyzed by metal phthalocyanine complex [34]. Pc also has promising use in chemical sensor as shown by Braik et al. [35] where they used $\mathrm{Co}(\mathrm{II})$ phthalocyanine acrylate polymer for perchlorate anion detection [35]. In the field of medicine, derivatives of $\mathrm{pc}$ are now being used in photodynamic therapy of cancer as they show strong absorption in far red-light in the wavelength $600-800 \mathrm{~nm}[35,36]$. Pc derivatives are a promising photosensitizer in fight of pathogenic microbes.

However, many potent phthalocyanines are hydrophobic and are poorly soluble in water [37]. Studies have shown that solubility of phthalocyanine plays a major role in determining its electrochemical, chemical, and physical properties $[9,12]$. As a result, advanced modification of the macrocycle structure of this compound is being done to improve its efficacy [2]. The solubility of Pc can be improved by attaching functional groups such as thiols, amines, sulphonyls ethers, and alkyl chains at the peripheral region of the macrocycle [6]. The specificity and its photo physical properties such as quantum yield of singlet oxygen can be enhanced by conjugating the Pc with metal nanoparticles such as $\mathrm{Ag}, \mathrm{Zn}, \mathrm{Co}, \mathrm{Fe}$, and other metal nanoparticles [11, 12]. For example, studies done by Rapulenyane 2013 showed an increase in quantum yield of oxygen from 0.26 to 0.57 when silver nanoparticles were included in Tris\{11,19,27-(1,2-diethylaminoethylthiol)-2(captopril) phthalocyanines\} $\mathrm{Zn}$ as shown in Table 2. The number of cationic charges and the way the cationic charges are distributed affects amphiphilic character of the pc which is an important property in photodynamic inactivation of microbes $[25,26]$.

\section{Phthalocyanine as Antimicrobial Agent}

Novel phthalocyanines that have been developed have shown good inactivation of various microbial pathogens [16]. A number of communications have reported that Gram-positive bacteria are more susceptible to Pc compared with Gramnegative bacteria. Lipopolysaccharide is the main constituent that makes the outer membrane in Gram-negative bacterium surface [38]. It protects the bacteria from attacks from chemicals and other compounds that may interfere with internal structures such as the lipid bilayer [21]. It is highly anionic in nature and this makes it an important pathway for cationic compounds such as photosensitizers [39]. The outer layer of Gram-negative also consists of phospholipid layer [25, 40]. This layer is effective in protecting Gram-negative bacteria against molecules from outside making them not to be susceptible to various antimicrobial drugs [14, 41]. The phospholipid layer is composed of biomembranes that have lipophilic cores and hydrophilic surfaces making them permeable to water soluble molecules [21]. The permeability decreases toward the center of the biomemberanes [42].

\section{Effect of Metal Nanoparticles}

The central atom linked to phthalocyanine is also an important parameter in enhancing the antimicrobial property of 
TABLE 2: Generation of quantum yield of singlet oxygen $(\Phi \Delta)$ and fluorescence $(\Phi F)$ for various phthalocyanines in dimethyl sulfoxide (DMSO).

\begin{tabular}{|c|c|c|c|}
\hline Phthalocyanine & $\Phi \Delta$ & $\Phi F$ & Ref. \\
\hline \{tetrakis-[1-(4-Bromophenyl)ethoxy]phthalocyaninato\}zinc(II) & 0.67 & 0.10 & [14] \\
\hline Cu-tris(hydroxymethyl)-trihidroximetil- phthalocyanine & 0.05 & & [6] \\
\hline \{tetrakis-[S-1-(4-Bromophenyl)ethoxy]phthalocyaninato\}zinc(II) & 0.65 & 0.10 & [14] \\
\hline Zinc phthalocinine & 0.67 & & [6] \\
\hline \{tetrakis-[R-1-(4-Bromophenyl)ethoxy]phthalocyaninato\}zinc(II) & 0.76 & 0.12 & {$[14]$} \\
\hline Cu-tris(hydroxyethylaminomethyl)- phthalocyanine & 0.02 & & [6] \\
\hline 4 iron phthalocyanines & 0.9 & & {$[6]$} \\
\hline Hydroxyaluminium phthalocyanine $(\mathrm{AlPcOH})$ & 0.41 & & {$[6]$} \\
\hline $\mathrm{Zn}(\mathrm{II})$ phthalocyanine with fluconazole (ZnPcF) & 0.14 & 0.19 & [15] \\
\hline $\begin{array}{l}\text { Tris }\{11,19,27-(1,2-\text { diethylaminoethylthiol)-2-(captopril) } \\
\text { phthalocyanines }\} \mathrm{Zn}\end{array}$ & 0.26 & 0.1 & {$[16]$} \\
\hline $\begin{array}{l}\text { Tris }\{11,19,27-(1,2-\text { diethylaminoethylthiol)-2-(captopril) } \\
\text { phthalocyanines }\} \text { Zn conjugated to silver nanoparticles }\end{array}$ & 0.57 & 0.058 & {$[16]$} \\
\hline Octacationic Zn(II)-phthalocyanine & 0.6 & - & [17] \\
\hline Tetracationic phthalocyanine & 0.73 & 0.12 & [18] \\
\hline
\end{tabular}

this compound. The central metal ion helps in increasing the quantum yield and the lifetime of the triplet; this in turn helps in the generation of singlet oxygen that helps in destruction of pathogenic microbes $[18,41]$. Conjugation of metal nanoparticle to Pc improves retention and permeability effect and also reduces the aggregation in aqueous media and biological tissues [43]. Studies done by Vallemolinares et al. showed a more enhanced antimicrobial activity from Pc with central metal linked [19]. The antimicrobial activity was more on diamagnetic metal attached to the Pc like zinc as compared to the paramagnetic linked like iron and vanadium [12]. There was a high inhibition percentage of $100 \%$ on Escherichia coli when subjected to Pc linked zinc Table 4 [19]. This may be attributed to the photo-toxins generated by singlet oxygen and also the reactive oxygen species arising from photochemical reaction of pathway I [25].

The cationic photosensitizers compete with other positively charged ions such as $\mathrm{Mg}^{2+}$ and $\mathrm{Ca}^{2+}$ on the surface of bacteria that stabilize the membrane structure of the bacteria [21]. Substitution of these important ions weakens the outer membrane allowing intake of photosensitizers that will inactivate the bacteria. Rapulenyane synthesized zinc phthalocyanine tetrasulphonate and zinc phthalocyanines tetrapyridine for the purpose of inactivation of microbes [16]. The study indicated that the balance between hydrophobicity and the charge is an important function in photodynamic therapy of microbes [16]. Different cationic charges in Pcs have shown activity against Gram-negative bacteria as evidenced by study that demonstrated that $E$. coli was susceptible to water soluble pcs of different charge [16]. Chromium (III) phthalocyanine chloride complex synthesized by Mugdad and Aziza [22] showed high activity when subjected to E. coli, Pseudomonas aeruginosa, and $S$. aureus with inhibition zone of 12, 9, and $10 \mathrm{~mm}$, respectively, as shown in Table 4 . When tested as antifungal against Candida albicans and Aspergillus flavus, it showed negligible activity against these fungal species [22].
The antimicrobial activity of this compound may be attributed to formation of hydrogen bond through the tertiary nitrogen of the isoindole ring of phthalocyanine with the active center of the microbial cell. This ends up in interference of metabolic process of the normal cell in these microbes [22]. The fungi S. aureus and Cryptococcus neoformans were successfully photo-inactivated with nanoemulsion of chloroaluminium phthalocyanine [43].

Previous studies by Kalhotka et al. indicated that differently charged pcs respond differently to Gram-positive and Gram-negative bacteria [24]. The studies showed that neutral and negatively charged pcs were effective only against Grampositive bacteria, while Gram-negative bacteria were only susceptible to cationic pcs $[18,26]$. This is because overall wall of Gram-negative bacteria is highly negatively charged and only allows cation to get through the impermeable membrane [19]. Cationic nanoemulsion of aluminium phthalocyanine showed a higher antiviral activity against herpes simplex virus type 1 and vesicular stomatitis virus as compared to the counterpart anionic nanoemulsion [43].

Amphiphilic character of photo sensitizer is an important property in photodynamic inactivation of microbes. This property may be enhanced by cationic charges, the number of these cationic charges, distribution of cationic charge, and the substituted group at lipophilicity of photo sensitizer molecule $[17,26]$. The positive charges attached to the photo sensitizer play an important role in targeting both the cellular and intracellular components like mitochondria of microbial cell where photocytotoxic activity occurs.

\section{Effect of the Number of Cationic Charges}

Photo sensitizers with one or more cationic groups have shown to be effective in photo inactivation of both Grampositive and Gram-negative bacteria $[17,21]$. The positive 
charges help in orienting the photo sensitizers toward destabilizing cell function and cell organization of the microbial cell [26]. Segalla et al. confirmed that cationic phthalocyanine is efficient photosensitizers of both Gram-negative and Gram-positive bacteria [17]. Using octacationic $\mathrm{Zn}$ (II)phthalocyanine with singlet quantum yield of 0.6 , they were able to inactivate E. coli by $5 \log$ [17]. Research done by Mantareva et al. using different cationic charges attached to $\mathrm{Pc}$ showed varied results on photodynamic inactivation of bacteria [44]. $\mathrm{Zn}(\mathrm{II}), \mathrm{Ga}(\mathrm{III})$, and $\mathrm{Si}(\mathrm{IV})$ metal cation in tetra-Nmethylpyridyloxy-phthalocyanine had higher fluorescence quantum yields and singlet oxygen quantum yield as compared to In (III) and Ge (IV) as shown in Table 4 [44]. Zn (II) and Si (IV) have higher singlet oxygen quantum yields of 0.41 and 0.68 , respectively, that may be attributed to them having closed $\mathrm{p}$ or $\mathrm{d}$ electrons [44]. Because of this high quantum yield of $\mathrm{Zn}$ (II) and Si (IV), the study indicated total inactivation of $S$. aureus strains when subjected to this pcs. The high quantum yield helps in generating the singlet oxygen through type II reaction that is phototoxic to microbes [44].

Porphyrins with different cationic charge have been successfully tested in fight against microbes. Research done by Simões et al. showed that porphyrins with tri- or tetrapositive charges were more efficient in inactivation of both Gram ( - ) and Gram (+) bacteria with inactivation almost to $100 \%$ [45]. Alves and coworkers showed that tri- and tetracationic porphyrin at $5.0 \mathrm{microM}$ with a light fluence of $64.8 \mathrm{~J} \mathrm{~cm}(-2)$ led to photoinactivation of both Enterococcus faecalis and E coli with $>7.0 \log$ (>99.999\%) [46]. A tricationic porphyrin with trifluoromethyl substituent conjugated to Pd (II) metal complex synthesized by Cells et al. showed high inactivation of almost $100 \%$ of E. coli than monocationic and dicationic porphyrin [47]. Tri cationic porphyrins showed high sensitivity in inactivation of bacteria because of lipophilic trifluoromethyl group that enhances amphiphilic property $[25,48,49]$.

\section{Effect of Cationic Charge Distribution}

The charge distribution in a photosensitizer affects microbial photodynamic inactivation effect. Studies by Cells et al. indicated that dicationic porphyrins having two cations in adjacent meso-phenyl had a highly polarized charge distribution increasing its amphiphilicity property [47]. They suggested that this might be the reason why the photo sensitizer is highly absorbed within the cell [47]. The adjacent positive charges at periphery of a photo sensitizer enhance penetration into the membrane of a microbe than cationic group in opposite position of a photo sensitizer [47]. This is a result of increase in affinity to the lipids $[25,50]$. Simões et al. also demonstrated that charge distribution affects the level of photo dynamic inactivation of bacteria [45]. Other studies indicate that dicationic porphyrins with trimethylammonium with the positive charges being at adjacent position was more efficient in photodynamic inactivation of $E$. coli than with the positive charges positioned at opposite sides [45]. The high efficient brought about by cations being in adjacent side is due to the distribution of macrocycle brought about by electrostatic repulsion between the nearby charged particles $[17,25]$.

\section{Substitution Functional Groups in the Pc}

Studies have shown that most bacteria pathogens are susceptible to Pcs modified with functional group in the peripheral position of the microcycles [24]. This is as a result of improvement of photochemical and photo physical properties of the pc such as generation of singlet oxygen and intersystem crossing [18, 39].

Compounds 2, 9, 16, and 23-tetra-phenyliminophthalocyanine synthesized by Khan et al. [20] showed maximum inhibition of $100 \%$ when it was tested for its antifungal properties against $A$. flavus and $A$. niger. This may be a result of nuclei damage and cytoplasmic membrane damage by the photosensitizer Pc [51].

Vallemolinares et al. investigated the effect of tetra-carboxy phthalocyanine against resistant strain microbes $S$. aureus, Klebsiella pneumoniae, and E. coli [19]. The results showed a higher inhibition of over $80 \%$ on all the tested strains of microbes mentioned (Table 3) [19]. The effectiveness of this compound as antimicrobial may be attributed to inclusion of carboxyl group in phthalocyanine structure that provided adhesion of this molecule on the surface of the microbes [19]. Antimicrobial property of phthalocyanine may have also been increased by the carbonyl group by enhancing its appropriate wavelength, thus increasing production of reactive oxygen species and singlet oxygen [19].

Synthesized 2, 9, 16, and 23-tetra-phenyliminophthalocyanines by Khan showed a high antimicrobial effect against strains of Xanthomonas shown in Table 3 [20]. The high zone of inhibition of the compound was also observed when it was tested against fungi $A$. Niger. Imino substituent makes phthalocyanine be more strong and potent antimicrobial agent [20]. This may be attributed to the substituted imino increasing thermal stability and chemical properties of phthalocyanine [20]. It also makes the phthalocyanine absorb light at a proper wavelength, thus generating more reactive oxygen species and singlet oxygen [20].

\section{Conclusions}

The structure of phthalocyanine offers a wide range of possibilities for designing different phthalocyanine derivatives showing efficacy in photodynamic inactivation of microbes. Studies reviewed herein show that Pcs modified by functionalization with various chromophores, conjugation with metal nanoparticles, and varying the position of cationic charge distribution in its microcircle. The antimicrobial properties of novel phthalocyanine are mainly due to singlet oxygen that is phototoxic to microbial cell generated as a result of type II chemical reaction. It is notable that a good phthalocyanine to be used as antimicrobial should have high quantum yield in order to generate more singlet oxygen. Despite the advantages of phthalocyanine and the milestones made towards the advancement of its effective against microbes, it is paramount to conduct more research towards this course. There is also need for more research to determine the effectiveness of the 
TABLE 3: Concentration, target microbes, efficacy reduction, and inhibition of different derivatives of phthalocyanine.

\begin{tabular}{|c|c|c|c|c|c|}
\hline Pc & Concentration & Target microbes & $\begin{array}{l}\text { Efficacy } \\
\text { reduction }\end{array}$ & $\begin{array}{l}\text { Inhibition zone/\% } \\
\text { reduction }\end{array}$ & Ref. \\
\hline Zinc-tetra(4-carboxyphenyl)Pc & $39.5 \mu \mathrm{g} / \mathrm{mL}$ & Escherichia coli & & $100.00 \%$ & [19] \\
\hline Zinc-tetra(4-carboxyphenyl)Pc & $22.02 \mu \mathrm{g} / \mathrm{L}$ & Enterococcus faecalis & & $32.91 \%$ & {$[19]$} \\
\hline Zinc-tetra(4-carboxyphenyl)Pc & $10.43 \mu \mathrm{g} / \mathrm{mL}$ & Klebsiella pneumonia & & $100.00 \%$ & {$[19]$} \\
\hline Zinc-tetra(4-carboxyphenyl)Pc & $22.48 \mu \mathrm{g} / \mathrm{mL}$ & Pseudomonas aeruginosa & & $12.25 \%$ & [19] \\
\hline Zinc-tetra(4-carboxyphenyl)Pc & $16.03 \mu \mathrm{g} / \mathrm{Ml}$ & Staphylococcus aureus & & $72.22 \%$ & {$[19]$} \\
\hline $\begin{array}{l}\text { Cobalt } 2,9,16,23 \text {-tetra- } \\
\text { phenyliminophthalocyanine }\end{array}$ & 500 ppm & $\begin{array}{c}\text { Xanthomonas campestris } \\
\text { Xanthomonas citri }\end{array}$ & & $\begin{array}{l}16 \mathrm{~mm} \\
17 \mathrm{~mm}\end{array}$ & {$[20]$} \\
\hline $\begin{array}{l}\text { Copper } 2,9,16,23 \text {-tetra- } \\
\text { phenyliminophthalocyanine }\end{array}$ & $500 \mathrm{ppm}$ & $\begin{array}{c}\text { Xanthomonas campestris } \\
\text { Xanthomonas citri }\end{array}$ & & $\begin{array}{l}19 \mathrm{~mm} \\
19 \mathrm{~mm}\end{array}$ & {$[20]$} \\
\hline $\begin{array}{l}\text { Nickel 2, 9, 16, 23-tetra- } \\
\text { phenyliminophthalocyanine }\end{array}$ & $500 \mathrm{ppm}$ & $\begin{array}{c}\text { Xanthomonas campestris } \\
\text { Xanthomonas citri }\end{array}$ & & $\begin{array}{l}18 \mathrm{~mm} \\
18 \mathrm{~mm}\end{array}$ & {$[20]$} \\
\hline $\begin{array}{l}\text { Zinc } 2,9,16,23 \text {-tetra- } \\
\text { phenyliminophthalocyanine }\end{array}$ & $500 \mathrm{ppm}$ & $\begin{array}{c}\text { Xanthomonas campestris } \\
\text { Xanthomonas citri }\end{array}$ & & $\begin{array}{l}19 \mathrm{~mm} \\
19 \mathrm{~mm}\end{array}$ & {$[20]$} \\
\hline Zinc phthalocyanine(neutral) & $2 \mathrm{mM}$ & Aeromonas hydrophila & $<0.5 \log$ & & {$[21]$} \\
\hline Tetra zinc (II)phthalocyanine & $64 \mathrm{ng} / \mathrm{mL}$ & Staphylococcus aureus & $5-6 \log s$ & & {$[21]$} \\
\hline $\begin{array}{l}\text { Cationic zinc(II)phthalocyanine } \\
\text { substituted with triamino }\end{array}$ & $13 \mathrm{nM}$ & Staphylococcus aureus & $4 \operatorname{logs}$ & & {$[21]$} \\
\hline $\begin{array}{l}\text { Neutral uncharged } \\
\text { Zn(II)pyridyloxyphthalocyanine }\end{array}$ & $10 \mu \mathrm{M}$ & Escherichia coli & $0.5 \operatorname{logs}$ & & {$[21]$} \\
\hline $\begin{array}{l}\text { Chromium (III) phthalocyanine } \\
\text { chloride complex }\end{array}$ & & Escherichia coli & & $12 \mathrm{~mm}$ & {$[22]$} \\
\hline $\begin{array}{l}\text { Chromium (III) phthalocyanine } \\
\text { chloride complex }\end{array}$ & & Pseudomonas aeruginosa & & $9 \mathrm{~mm}$ & {$[22]$} \\
\hline $\begin{array}{l}\text { Chromium (III) phthalocyanine } \\
\text { chloride complex }\end{array}$ & & Staphylococcus aureus & & $10 \mathrm{~mm}$ & [22] \\
\hline $\begin{array}{l}\text { Chromium (III) phthalocyanine } \\
\text { chloride complex }\end{array}$ & & Bacillus cereus & & $11 \mathrm{~mm}$ & {$[22]$} \\
\hline 2,9,16,23-Tetra-N-[4-(5-phenyl- & & Staphylococcus aureus & & $23 \mathrm{~mm}$ & \\
\hline $\begin{array}{l}\text { 1,3,4-oxadiazol-2- } \\
\text { yl)phenyl]benzamido- } \\
\text { nickelphthalocyanines } \\
2,9,16,23 \text {-Tetra-N-[4-(5-phenyl- }\end{array}$ & $40 \mu \mathrm{g} / \mathrm{mL}$ & $\begin{array}{l}\text { Pseudomonas aeruginosa } \\
\text { Klebsiella pneumonia } \\
\text { Staphylococcus aureus }\end{array}$ & & $\begin{array}{l}27 \mathrm{~mm} \\
28 \mathrm{~mm} \\
25 \mathrm{~mm}\end{array}$ & {$[23]$} \\
\hline $\begin{array}{l}\text { 1,3,4-oxadiazol-2- } \\
\text { yl)phenyl]benzamido-cobalt } \\
\text { phthalocyanine } \\
2,9,16,23 \text {-Tetra-N-[4-(5-phenyl- }\end{array}$ & $40 \mu \mathrm{g} / \mathrm{mL}$ & $\begin{array}{l}\text { Pseudomonas aeruginosa } \\
\text { Klebsiella pneumoniae } \\
\text { Staphylococcus aureus }\end{array}$ & & $\begin{array}{l}26 \mathrm{~mm} \\
29 \mathrm{~mm} \\
26 \mathrm{~mm}\end{array}$ & {$[23]$} \\
\hline $\begin{array}{l}\text { 1,3,4-oxadiazol-2- } \\
\text { yl)phenyl]benzamido-cobalt } \\
\text { phthalocyanine }\end{array}$ & $40 \mu \mathrm{g} / \mathrm{mL}$ & $\begin{array}{l}\text { Pseudomonas aeruginosa } \\
\text { Klebsiella pneumoniae }\end{array}$ & & $\begin{array}{l}27 \mathrm{~mm} \\
28 \mathrm{~mm}\end{array}$ & [23] \\
\hline $\begin{array}{l}\text { Zinc phthalocyanine with } \\
\text { sulphamidic substituents }\end{array}$ & $50 \mathrm{mg} / 100 \mathrm{ml}$ & $\begin{array}{c}\text { Pseudomonas aeruginosa } \\
\text { Escherichia coli } \\
\text { Enterococcus faecalis }\end{array}$ & $\begin{aligned} & 6 \log \\
& 4 \log \\
< & 0.5 \log \end{aligned}$ & & [24] \\
\hline $\begin{array}{l}\text { Tris }\{11,19,27-(1,2- \\
\text { diethylaminoethylthiol)-2- } \\
\text { (captopril) phthalocyanines } \\
\text { Zn }\end{array}$ & $20 \mathrm{uM}$ & Escherichia coli & & $90 \%$ & {$[16]$} \\
\hline $\begin{array}{l}\text { Tris }\{11,19,27-(1,2- \\
\text { diethylaminoethylthiol)-2- } \\
\text { (captopril) phthalocyanines } \mathrm{Zn} \\
\text { conjugated to silver nanoparticles }\end{array}$ & $20 \mathrm{uM}$ & Escherichia coli & & $95 \%$ & {$[16]$} \\
\hline
\end{tabular}


TABLE 4: Fluorescence quantum yields and singlet oxygen quantum yield of tetra-N-methylpyridyloxy-phthalocyanine with different metal cations in DMSO.

\begin{tabular}{lcc}
\hline Metal cation & $\begin{array}{c}\text { Fluorescence quantum } \\
\text { yields } \Phi F\end{array}$ & $\begin{array}{c}\text { Singlet oxygen quantum } \\
\text { yield } \Phi \Delta\end{array}$ \\
\hline Zn (II) & 0.33 & 0.41 \\
Ga (III) & 0.25 & 0.36 \\
In (III) & 0.012 & 0.26 \\
Ge (IV) & 0.013 & 0.31 \\
Si (IV) & 0.19 & 0.68 \\
\hline
\end{tabular}

charge distribution on the microcycle of phthalocyanine and the effect of the number of cationic charges on photodynamic inactivation of microbes. There is need to determine the effectiveness of conjugation of various metal nanoparticles and cationic substituted phthalocyanine in comparison with the modern drugs that are no longer effective against microbes.

\section{Conflicts of Interest}

The authors declare no conflicts of interest.

\section{Acknowledgments}

This review is part of the research work financially supported by the National Research Fund (Grant NRF2017/2018FY), Kenya, and a Ph.D. scholarship by Africa Development Bank and Ministry of Higher Education at Kenyatta University.

\section{References}

[1] WHO, "Antimicrobial resistance," Bulletin of the World Health Organization, vol. 61, no. 3, pp. 383-394, 2014.

[2] T. G. S. Denis and M. R. Hamblin, "An introduction to photoantimicrobials: photodynamic therapy as a novel method of microbial pathogen eradication," Science against Microbial Pathogens: Communicating Current Research and Technological Advances, pp. 675-683, 2011.

[3] CDC, "Antibiotic resistance threats in the United States," Current, p. 114, 2013.

[4] R. E. Siegel, "Emerging gram-negative antibiotic resistance: daunting challenges, declining sensitivities, and dire consequences," Respiratory Care, vol. 53, no. 4, pp. 471-479, 2008.

[5] L. Amaral, M. Viveiros, and J. Molnar, "Antimicrobial activity of phenothiazines," In Vivo, vol. 18, no. 6, pp. 725-732, 2004.

[6] A. Staicu, A. Pascu, A. Nuta, A. Sorescu, V. Raditoiu, and M. L. Pascu, "Studies about phthalocyanine photosensitizers to be used in photodynamic therapy," Romanian Reports in Physics, vol. 65, no. 3, pp. 1032-1051, 2013.

[7] H. Huang, W. Song, J. Rieffel, and J. F. Lovell, "Emerging applications of porphyrins in photomedicine," Frontiers of Physics, vol. 3, no. 23, pp. 1-15.

[8] I. N. Okeke and A. Sosa, "Antibiotic resistance in Africa - discerning the enemy and plotting a defense," Africa Health, vol. 25, pp. 10-15, 2003.

[9] "Republic of kenya national policy on prevention and containment of antimicrobial resistance," 2017.
[10] J. B. Ndihokubwayo, A. A. Yahaya, A. T. Desta, and G. Kizerbo, "Antimicrobial resistance in the African Region: Issues, challenges and actions proposed," no. 16.

[11] A. N. Kimang'a, "A situational analysis of antimicrobial drug resistance in Africa: are we losing the battle?" Ethiopian Journal of Health Sciences, vol. 22, no. 2, pp. 135-143, 2012.

[12] R. Kirika, Antimicrobial Resistance: The Need for Action in The East, Central And Southern Africa Region, 2009.

[13] X.-J. Fu, Y. Fang, and M. Yao, "Antimicrobial photodynamic therapy for methicillin-resistant Staphylococcus aureus infection," BioMed Research International, vol. 2013, Article ID 159157, 9 pages, 2013.

[14] A. A. Ramos, F. B. Nascimento, T. F. M. De Souza et al., "Photochemical and photophysical properties of phthalocyanines modified with optically active alcohols," Molecules, vol. 20, no. 8, pp. 13575-13590, 2015.

[15] M. Paula Cormick, M. Rovera, and E. N. Durantini, "Synthesis, spectroscopic properties and photodynamic activity of a novel $\mathrm{Zn}$ (II) phthalocyanine substituted by fluconazole groups," Journal of Photochemistry and Photobiology A: Chemistry, vol. 194, no. 2-3, pp. 220-229, 2008.

[16] N. Rapulenyane, Photophysicochemical and photodynamic antimicrobial chemotherapeutic studies of novel phthalocyanines conjugated to silver nanoparticles [M.S. thesis], 2013, February, pp. $1-134$.

[17] A. Segalla, C. D. Borsarelli, S. E. Braslavsky et al., "Photophysical, photochemical and antibacterial photosensitizing properties of a novel octacationic Zn(II)-phthalocyanine," Photochemical \& Photobiological Sciences, vol. 1, no. 9, pp. 641-648, 2002.

[18] C. Fabris, M. Soncin, E. Mazzon et al., "A novel tetracationic phthalocyanine as a potential skin phototherapeutic agent," Experimental Dermatology, vol. 14, no. 9, pp. 675-683, 2005.

[19] R. H. Vallemolinares, P. R. D. Romero, O. R. M. Quigua, L. W. A. Vallejo, U. C. E. Díaz, and V. J. W. Arboleda, "Antimicrobial activity of metallo tetra (4-carboxyphenyl) phthalocyanine useful in photodynamic therapy," Pharmacologyonline, vol. 2, pp. 131-137, 2015.

[20] M. H. Moinuddin Khan, K. R. Venugopala Reddy, and J. Keshavayya, "Synthesis, spectral, magnetic, thermal and antimicrobial studies on symmetrically substituted 2, 9, 16, 23-tetraphenyliminophthalocyanine complexes," in A Search for Antibacterial Agents, V. Bobbarala, Ed., InTech, 2012.

[21] Y. Liu, R. Qin, S. A. J. Zaat, E. Breukink, and M. Heger, "Antibacterial photodynamic therapy: overview of a promising approach to fight antibiotic-resistant bacterial infections," Journal of Clinical and Translational Research, vol. 1, pp. 140-167, 2015.

[22] E. Mugdad and A. K. Aziza, "Preparation, characterization and biological activity of chromium phthalocyanine chloride complex," Sudan Journal of Science and Technology, vol. 13, no. 1, 2012.

[23] B. Chidanandaa, K. R. Venugopala Reddyb, M. N. K. Harishc et al., "Synthesis, spectral characterization, in vitro biological, antioxidant studies of 2,9,16,23- tetra-N-[4-(5-phenyl-1,3,4oxadiazol-2-yl)phenyl]benzamido- metallophthalocyanines," Der Pharma Chemica, vol. 5, no. 4, pp. 293-300, 2013.

[24] L. Kalhotka, Z. Hrdinová, R. Kořínková et al., "Test of phthalocyanines antimicrobial activity," Nanocon 2012, pp. 6-11, 2012.

[25] F. Cieplik, L. Tabenski, W. Buchalla, and T. Maisch, "Antimicrobial photodynamic therapy for inactivation of biofilms formed 
by oral key pathogens," Frontiers in Microbiology, vol. 5, article 405, 2014.

[26] X. Ragàs, X. He, M. Agut et al., "Singlet oxygen in antimicrobial photodynamic therapy: Photosensitizer- dependent production and decay in E. coli," Molecules, vol. 18, no. 3, pp. 2712-2725, 2013.

[27] M. Wainwright, Photosensitisers in Biomedicine, John Wiley \& Sons, Ltd, Chichester, UK, 2009.

[28] Y. Liang, L.-M. Lu, Y. Chen, and Y.-K. Lin, "Photodynamic therapy as an antifungal treatment (Review)," Experimental and Therapeutic Medicine, vol. 12, no. 1, pp. 23-27, 2016.

[29] J. Yang, Synthesis of Novel Red-Shifted Phthalocyanines, 2006.

[30] H. Mojzisova, S. Bonneau, and D. Brault, "Structural and physico-chemical determinants of the interactions of macrocyclic photosensitizers with cells," European Biophysics Journal, vol. 36, no. 8, pp. 943-953, 2007.

[31] B. Ertem, A. Bilgin, Y. Gök, and H. Kantekin, “The synthesis and characterization of novel metal-free and metallophthalocyanines bearing eight 16-membered macrocycles," Dyes and Pigments, vol. 77, no. 3, pp. 537-544, 2008.

[32] J. Hanna, "Towards a new horizon of optoelectronic devices with liquid crystals," Opto-Electronics Review, vol. 13, no. 4, pp. 259-267, 2005.

[33] M. G. Walter, A. B. Rudine, and C. C. Wamser, "Porphyrins and phthalocyanines in solar photovoltaic cells," Journal of Porphyrins and Phthalocyanines, vol. 14, no. 9, pp. 759-792, 2010.

[34] S. Faculty and O. Chemistry, Catalytic Applications of Heterogeneous Metal-Phthalocyanine Complexes Agnes Zsigmond Catalytic Applications of Heterogeneous Metal-Phthalocyanine Complexes Péter Bata, 2014.

[35] M. Braik, C. Dridi, M. Ben Ali et al., "Development of a capacitive chemical sensor based on $\mathrm{Co}(\mathrm{II})$-phthalocyanine acrylatepolymer $/ \mathrm{HfO}_{2} / \mathrm{SiO}_{2} / \mathrm{Si}$ for detection of perchlorate," Journal of Sensors and Sensor Systems, vol. 4, no. 1, pp. 17-23, 2015.

[36] T. Obata, S. Mori, Y. Suzuki et al., "Photodynamic Therapy Using Novel Zinc Phthalocyanine Derivatives and a Diode Laser for Superficial Tumors in Experimental Animals," Journal of Cancer Therapy, vol. 06, no. 01, pp. 53-61, 2015.

[37] M. Özceşmeci, I. Nar, and E. Hamuryudan, "Synthesis and electrochemical and spectroelectrochemical characterization of chloromanganese(III) phthalocyanines," Turkish Journal of Chemistry, vol. 38, no. 6, pp. 1064-1072, 2014.

[38] T. J. Beveridge, "Structures of gram-negative cell walls and their derived membrane vesicles," Journal of Bacteriology, vol. 181, no. 16, pp. 4725-4733, 1999.

[39] C. L. Friedrich, D. Moyles, T. J. Beveridge, and R. E. W. Hancock, "Antibacterial action of structurally diverse cationic peptides on gram- positive bacteria," Antimicrobial Agents and Chemotherapy, vol. 44, no. 8, pp. 2086-2092, 2000.

[40] Y. Fang, T. Liu, Q. Zou, Y. Zhao, and F. Wu, "Water-soluble benzylidene cyclopentanone based photosensitizers for in vitro and in vivo antimicrobial photodynamic therapy," Scientific Reports, vol. 6, Article ID 28357, 2016.

[41] R. Ruiz-González, M. Agut, E. Reddi, and S. Nonell, "A comparative study on two cationic porphycenes: Photophysical and antimicrobial photoinactivation evaluation," International Journal of Molecular Sciences, vol. 16, no. 11, pp. 27072-27086, 2015.

[42] M. Nikolić, S. Vasić, J. Đurđević, O. Stefanović, and L. Čomić, "Antibacterial and anti-biofilm activity of ginger (Zingiber officinale (Roscoe)) Ethanolic extract," Kragujevac Journal of Science, vol. 36192548, no. 581, pp. 129-136, 2014.
[43] I. Zafar, M. Arfan, N. Rp, and S. Aj, "Aluminum Phthalocyanine Derivatives: Potential in Antimicrobial PDT and Photodiagnosis," Austin Biomolecules: Open Access, vol. 1, no. 2, pp. 1-7, 2016.

[44] V. Mantareva, I. Angelov, D. Wöhrle, E. Borisova, and V. Kussovski, "Metallophthalocyanines for antimicrobial photodynamic therapy: an overview of our experience," Jounal of Porphyrins and Phthalocyanines, vol. 17, pp. 399-416, 2013.

[45] C. Simões, M. C. Gomes, M. G. P. M. S. Neves et al., "Photodynamic inactivation of Escherichia coli with cationic mesotetraarylporphyrins - The charge number and charge distribution effects," Catalysis Today, vol. 266, pp. 197-204, 2016.

[46] E. Alves, L. Costa, C. M. Carvalho et al., "Charge effect on the photoinactivation of gram-negative and gram-positive bacteria by cationic meso-substituted porphyrins," BMC Microbiology, vol. 9, article no. 70, 2009.

[47] H. Cells, T. J. Jensen, M. G. H. Vicente et al., "Syntheses and properties of trimethylaminophenoxy-substituted $\mathrm{Zn}$ (II)phthalocyanines," Medicinal Chemistry Communication, vol. 3, no. 2, pp. 179-194, 2012.

[48] V. Shivanna and R. Nilegaonkar, "Review articles photodynamics in dentistry," CODS Journal of Dentistry, vol. 7, no. 1, 2015.

[49] F. Nakonechny, M. Nisnevitch, Y. Nitzan, and M. A. Firer, "New techniques in antimicrobial photodynamic therapy: scope of application and overcoming drug resistance in nosocomial infections," Science against Microbial Pathogens: Communicating Current Research and Technological Advances, pp. 684-691, 2011.

[50] T. J. Jensen, M. G. H. Vicente, R. Luguya, J. Norton, F. R. Fronczek, and K. M. Smith, "Effect of overall charge and charge distribution on cellular uptake, distribution and phototoxicity of cationic porphyrins in HEp2 cells," Journal of Photochemistry and Photobiology B: Biology, vol. 100, no. 2, pp. 100-111, 2010.

[51] M. A. Paschoal and S. Duarte, "Photodynamic antimicrobial chemotherapy for prevention and treatment of dental caries: a critical review," OA Dentistry, vol. 1, no. 1, pp. 1-5, 2013. 

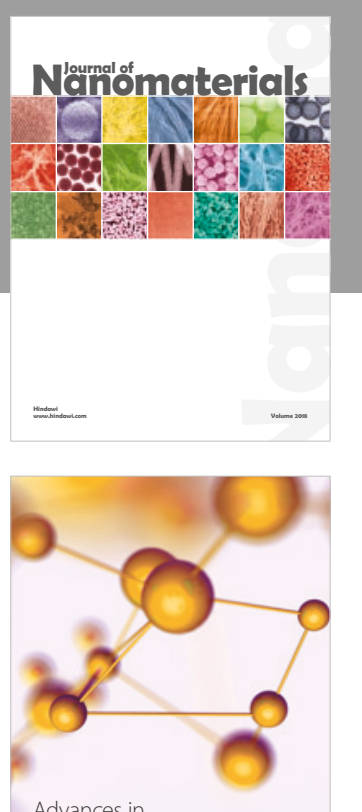

Physical Chemistry
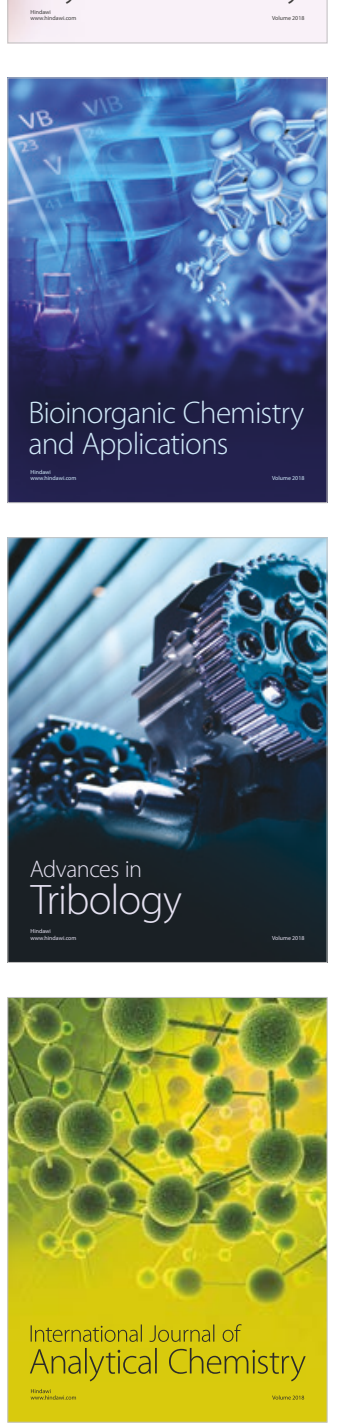

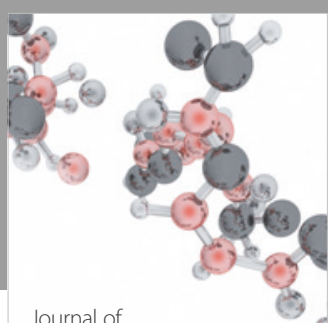

Analytical Methods

in Chemistry

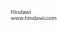

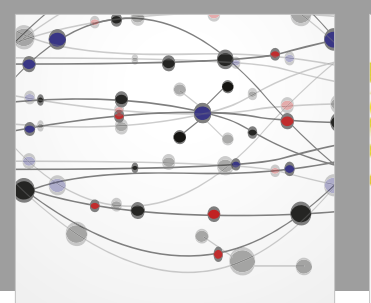

The Scientific World Journal

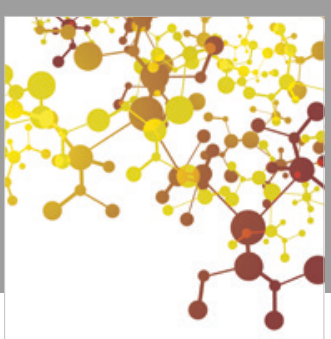

Journal of

Applied Chemistry
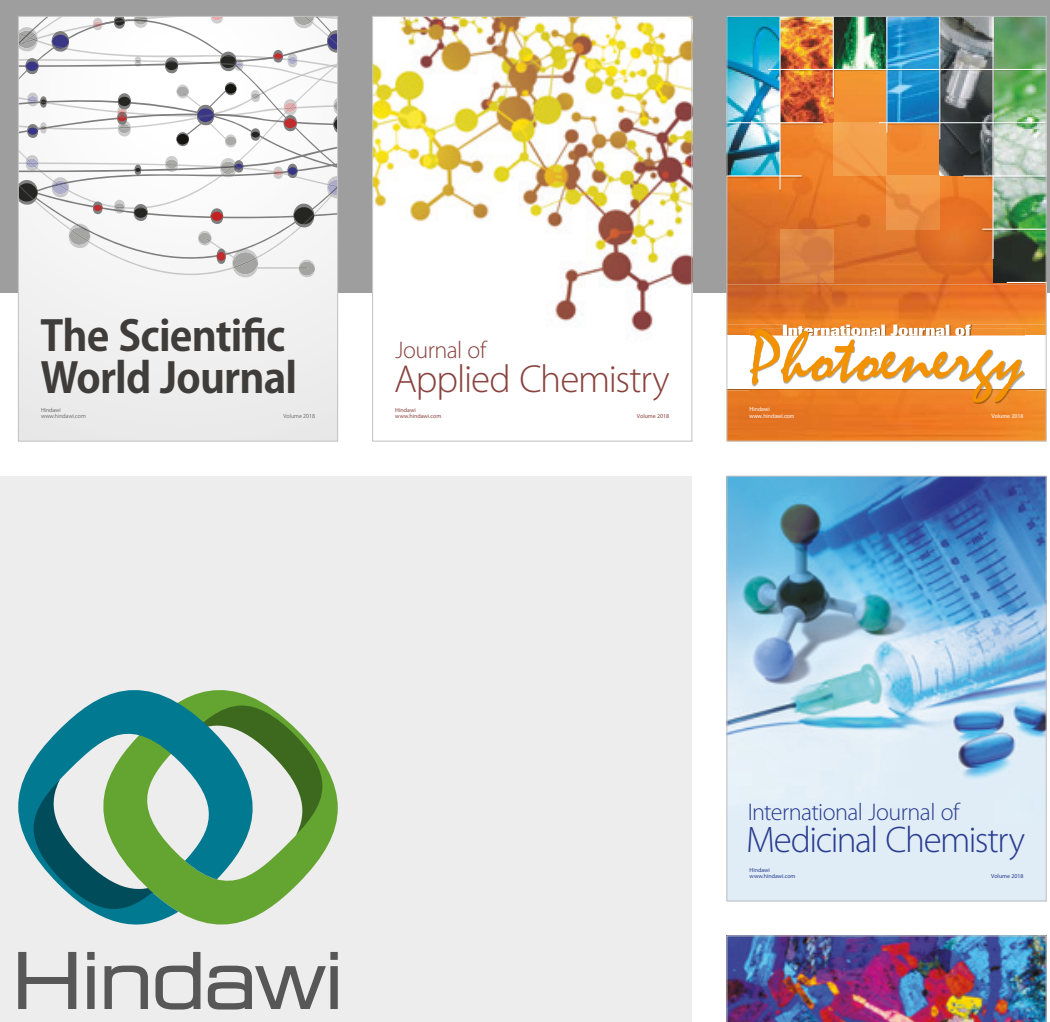

Submit your manuscripts at

www.hindawi.com
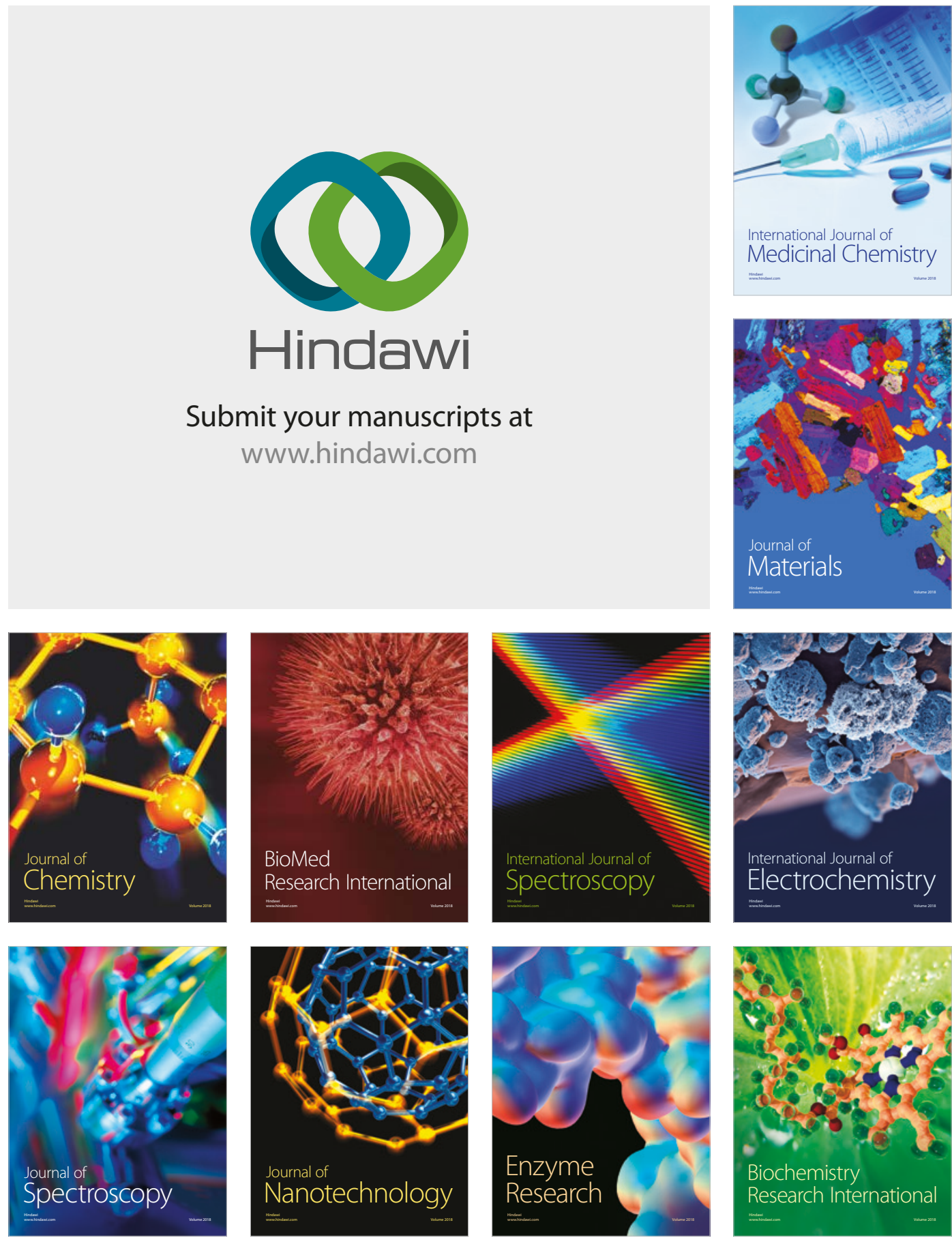
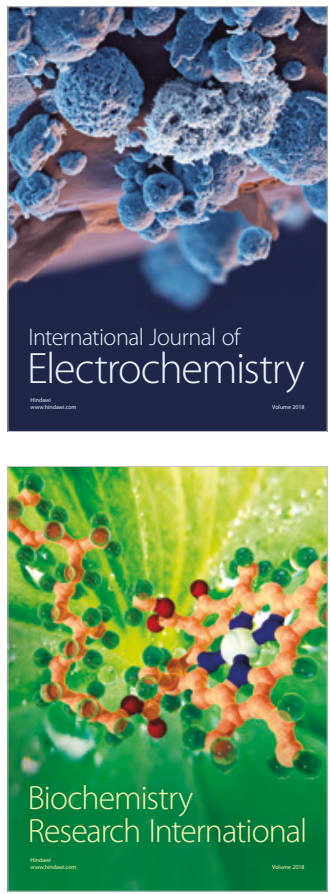